\title{
Behavior of reinforced concrete columns strenghtened by partial jacketing
}

\section{Estudo do comportamento de pilares de concreto armado reforçados pela técnica do encamisamento parcial e uso de conectores}

D. B. FERREIRA a borjadiego5@gmail.com

R. B. GOMES a rbggomes@gmail.com

A. L. CARVALHO carvalhoal@hotmail.com

G. N. GUIMARÃES a rgilson.natal@gmail.com

\begin{abstract}
This article presents the study of reinforced concrete columns strengthened using a partial jacket consisting of a $35 \mathrm{~mm}$ self-compacting concrete layer added to its most compressed face and tested in combined compression and uniaxial bending until rupture. Wedge bolt connectors were used to increase bond at the interface between the two concrete layers of different ages. Seven $2000 \mathrm{~mm}$ long columns were tested. Two columns were cast monolithically and named PO (original column) e PR (reference column). The other five columns were strengthened using a new $35 \mathrm{~mm}$ thick self-compacting concrete layer attached to the column face subjected to highest compressive stresses. Column PO had a $120 \mathrm{~mm}$ by $250 \mathrm{~mm}$ rectangular cross section and other columns had a $155 \mathrm{~mm}$ by $250 \mathrm{~mm}$ cross section after the strengthening procedure. Results show that the ultimate resistance of the strengthened columns was more than three times the ultimate resistance of the original column PO, indicating the effectiveness of the strengthening procedure. Detachment of the new concrete layer with concrete crushing and steel yielding occurred in the strengthened columns.
\end{abstract}

Keywords: columns, strengthening, concrete, bolts.

\section{Resumo}

Este artigo apresenta um estudo do comportamento de pilares de concreto armado reforçados por encamisamento parcial, com o uso de uma camada de $35 \mathrm{~mm}$ de concreto auto adensável na face mais comprimida submetidos à flexo-compressão até à ruptura. Foram utilizados parafusos conectores como armadura de ligação entre as duas camadas de concreto de diferentes idades. Foram ensaiados 7 pilares de $2000 \mathrm{~mm}$ de altura, sendo 2 peças concretadas monoliticamente nomeadas de PO (pilar original) e PR (pilar de referência). Os outros 5 pilares foram reforçados utilizando uma camada de $35 \mathrm{~mm}$ de concreto moldada na face submetida a maior compressão. O pilar PO tinha uma seção transversal retangular de 120x $250 \mathrm{~mm}$ e as demais colunas $155 \times 250 \mathrm{~mm}$ após executado o reforço. Os resultados alcançados mostram que os pilares reforçados atingiram uma resistência de aproximadamente três vezes maior com relação ao pilar PO, demostrando eficiência da técnica utilizada. Os pilares apresentaram o desplacamento da camada de reforço nas cargas finais, com tendências ao esmagamento do concreto e escoamento do aço.

Palavras-chave: pilares, reforço, concreto, parafusos. 


\section{Introduction}

Different types of pathologies can appear in structures which can cause a large number of problems and can ultimately lead to failure. Among these problems are design and execution flaws, use of low quality materials and changes in building use. A common strengthening technique for reinforced concrete structures consists of jacketing the member by adding new concrete to its sides increasing the size and resistance of the cross section. For a column strengthened using jacketing it is important to guarantee stress transfer at the new concrete/ old concrete interface. According to Gomes \& Appleton [1], this technique is usually more adequate when the need occurs to increase compressive strength, increase the size of the cross section or to add more steel reinforcement to the concrete cross section. It is necessary to avoid detachment of the new strengthening concrete added to a column member, when it is again at service loads, for the jacketing technique to work.

This article presents a study on the experimental behavior of seven reinforced concrete columns subjected to compression and uniaxial bending and strengthened by adding a self-compacting concrete layer to its most compressed face. This technique is frequently used in local construction. Sleeve wedge bolt connectors were used to increase bond at the old concrete-new concrete interface. The objective of this research is to analyze column behavior with respect to ultimate loading and the efficiency of the interaction of

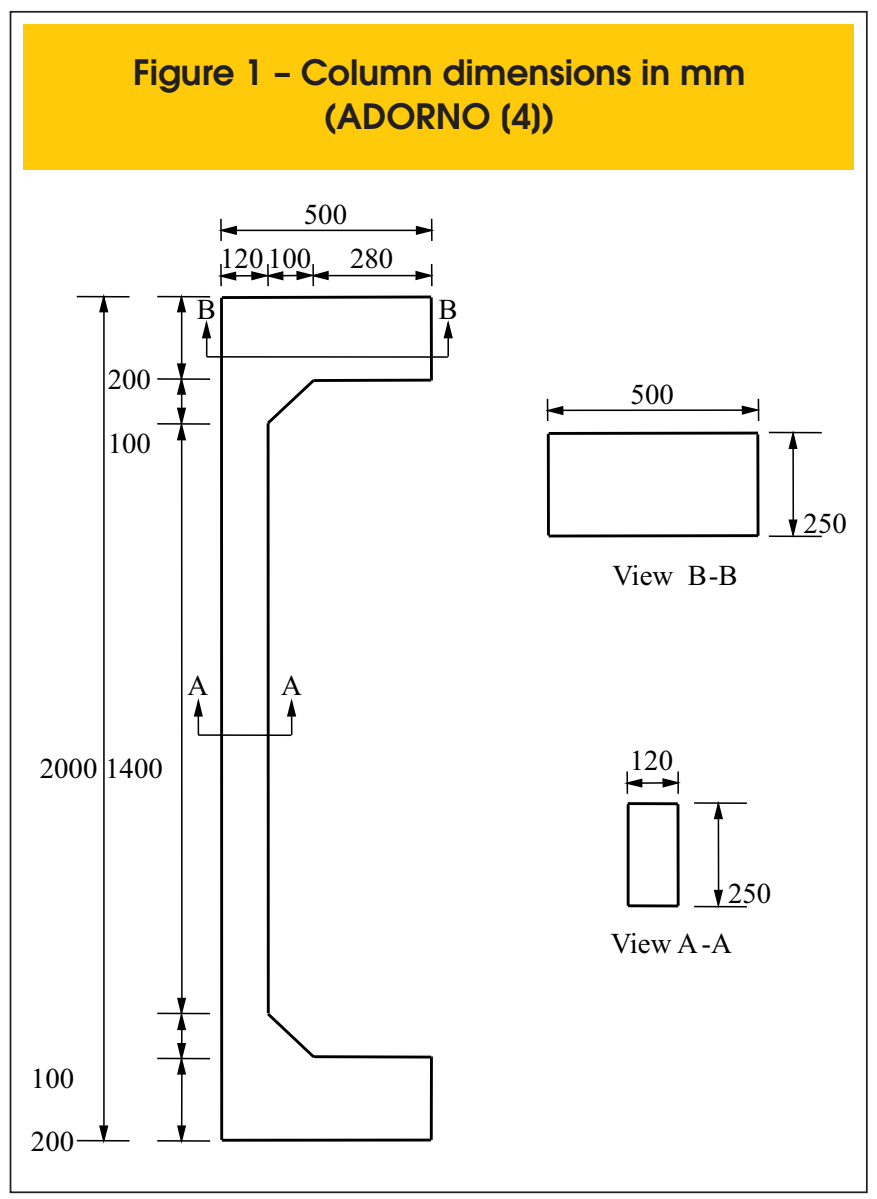

the two concrete layers of different ages as well as the behavior of connectors.

\section{Previous research}

Research on columns has been done to obtain design parameters for use in column design present in codes. Among such research, the study done by Ibrahim e MacGregor [2] analyzed the results obtained on tests of 20 columns (both reinforced and unreinforced) where high strength reinforced concrete was used. Much of the test setup used in this research was similar to the one used by Ibrahim e MacGregor [2]. Results show that the concrete cover of reinforced concrete columns detached at an average concrete strain between $4.0 \%$ and $4.5 \%$ for columns with a rectangular cross section, and between $4.7 \%$ and $5.2 \%$ for columns with a triangular cross section.

Adorno [3] started a series of studies done with the University of Brasilia (UnB) and the Federal University of Goias on reinforced concrete columns subjected to uniaxial bending and compression. Column dimensions and details of column steel reinforcement are shown in Figures 1 and 2 for the model column used in the study. Several researchers (Araújo [4], Omar [5], Sahb [6] e Nascimento [7]), at those two universities, followed Adorno's line of research. Except for Araujo [4], they followed through with studies on column strengthening using a concrete jacketing with self-compacting concrete (SCC) and different kinds of connectors at the new concreteold concrete interface were used.

Omar [5] researched column jacketing on different column faces using a layer of self-compacting concrete (SCC). The original columns were loaded until longitudinal steel yielding and then unloaded and strengthened with a concrete jacket. A new concrete layer was added to different column faces (compressive face, tension face and both faces). Stirrup shaped connectors ( $\Phi 5 \mathrm{~mm}$ bar diameter) and additional longitudinal steel were used in the new concrete layer.

Following Omar's research, Sahb [6] used wedge bolts as connectors between the two concrete layers of different ages in the jacketing procedure. Columns were reinforced on the most compressed side only with additional longitudinal reinforcement for shrinkage. The objective of the study was to minimize detachment of the new concrete layer and avoid a fragile mode of failure.

Open stirrups attached to the original column stirrups were used as connectors between the old substrate concrete and the new strengthening concrete in the work done by Nascimento [7]. The original column stirrups had to be exposed to anchor the new connector.

All columns tested by these researchers presented good results with increases in column ultimate capacity ranging from two to close to four times the resistance of the column without jacketing. However, a fragile mode of failure with detachment of the strengthening concrete layer occurred in almost all cases. Only one column tested by Nascimento [7] obtained a ductile mode of failure (without concrete cover detachment) and an increase in ultimate load capacity. New research is needed to minimize concrete detachment and obtain ductile failure. 


\section{Figure 2 - Steel reinforcement details (ADORNO (4))}

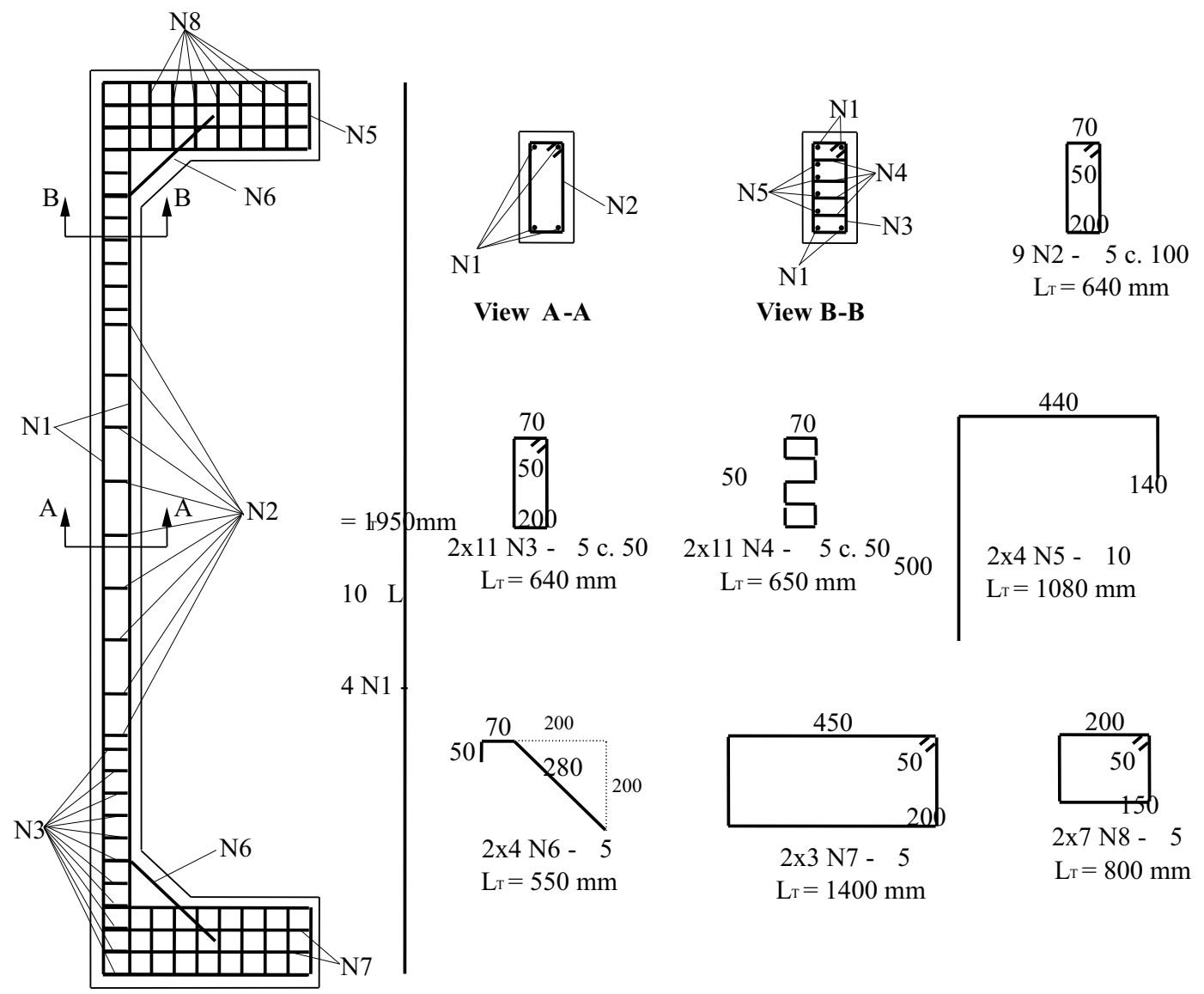

\section{Experimental program}

Development of this research was based on previous work done by Adorno [4] and Sahb [6]. The columns tested and the test setup had the same basic properties as their work, such as: concrete cross section, steel reinforcement, connector type, type of concrete and casting procedure.

Seven rectangular columns were tested subjected to compression and one-axis bending with and initial load eccentricity of $60 \mathrm{~mm}$. Five of the seven columns were strengthened at the most compressed face with the addition of a concrete layer (jacket) and use of wedge bolts along its length to increase adhesion between the old concrete substrate and the new concrete layer.

Column nominated as PO corresponds to the original column without strengthening with the rectangular cross section of $120 \mathrm{~mm}$ by $250 \mathrm{~mm}$. Five strengthened columns were originally cast with a $120 \mathrm{~mm}$ by $250 \mathrm{~mm}$ cross section and the jacket consisted of a $35 \mathrm{~mm}$ layer of self-compacting concrete was later added to the compression face. Therefore, the five strengthened columns had a $155 \mathrm{~mm}$ by $250 \mathrm{~mm}$ cross section when tested and all were strengthened with sleeve wedge bolts placed perpendicular to the concrete interface formed after adding the new concrete 35 $\mathrm{mm}$ layer. Connectors are shown in Figure 3 and were manually fixed to the column so that $15 \mathrm{~mm}$ of the connector was inside the

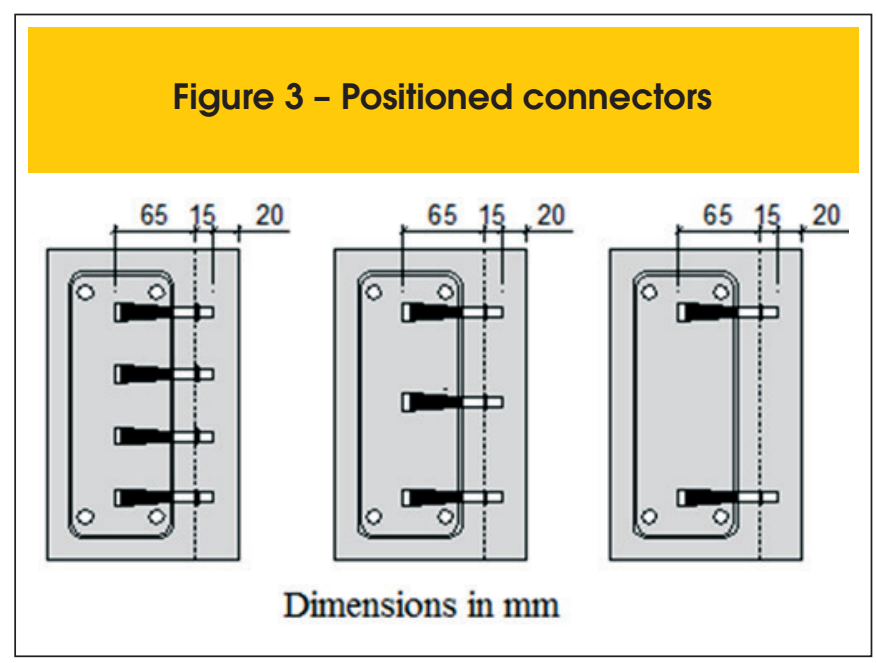


$35 \mathrm{~mm}$ reinforcing layer. Column nominated as $\mathrm{PR}$ was cast with a $155 \mathrm{~mm}$ by $250 \mathrm{~mm}$ cross section and has the same cross section as the strengthened columns but was cast monolithically. Since column PR was cast monolithically it should correspond to the strengthened column at its best as far as column load capacity is concerned. Column length was $2000 \mathrm{~mm}$.

The specimens were built with two corbels, one at the base and another at the top of the column, to avoid stress concentrations due to load application and to allow application of a vertical force with an eccentricity that will provide bending moment at the column mid-height so that the column will be under compression and uniaxial bending.

Two casts were made using self-compacting concrete. Columns with the original dimensions and the reference column were cast first, and the strengthening layer was added in a second cast. Specific testing on the fresh self-compacting concrete was done according to NBR 15823-1, namely: slump test, V-funnel test and L-Box test, using the equipment shown in Figure 4.

Testing was divided in two series. The first one tested four col-

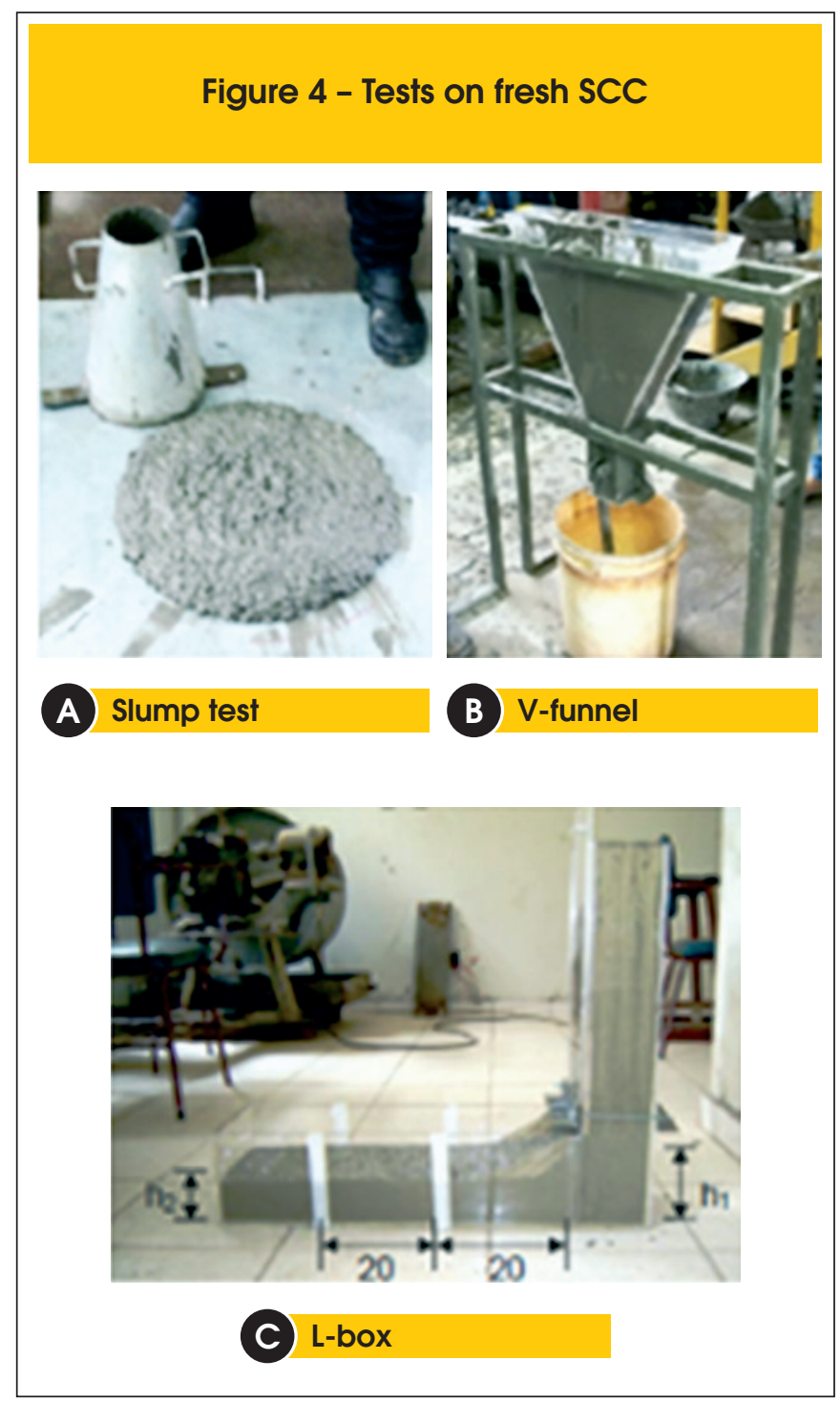

umns: the original column $\mathrm{PO}$, reference column $\mathrm{PR}$ and two strengthened columns nominated $\mathrm{P} 150-18$ e P150-26 with connectors spaced vertically every $150 \mathrm{~mm}$ following the same geometrical properties as Sahb's [6] research. Column P150-18 had a total of 18 connectors and P150-26 had a total of 26 connectors. Three columns with connectors spaced vertically every $100 \mathrm{~mm}$ were tested as the second series and they were nominated as P100-26, P100-38 e P100-50 and they had a total of 26,38 and 50 connectors, respectively. Figure 5 shows connector positioning for all columns.

During testing of column P100-26, a problem occurred with the hydraulic jack and testing was interrupted. Therefore, testing for column P100-26 was divided in two parts and the first part was renamed as P100-26a. After fixing the jack, reloading of the column was done and testing proceeded until rupture. This second part of the test was renamed as P100-26b and only a ruler and displacement indicator R3 were used as instrumentation.

Procedure for column jacketing were as follows: identification of original stirrup positions, identification for connector positioning, hole execution, old concrete scarification, connector placement, cleaning, concrete surface saturation and casting of new concrete layer (jacket).

Electrical resistance strain gauges positioned along the steel reinforcement and on the concrete surface at column mid-height were used to measure strains on the steel and concrete surface as shown in Figure 6.

Horizontal and vertical displacements were measured by digital displacement indicators as shown in Figure 7. These indicators had a $0.01 \mathrm{~mm}$ precision and a $50 \mathrm{~mm}$ gauge length. Indicator installation procedure consisted on mounting a fixed device on a vertical support placed behind the column and the indicator cursor was placed on small metal plates glued to the column's surface. Indicators were removed prior to rupture to avoid equipment damage. A complementary reading of mid-height displacement (same height as digital indicator R3 was placed) was taken using a standard measuring tape and it was used to measure horizontal mid-height displacements after removal of the digital indicators.

Figure 8 presents the test setup which is basically the column attached to a steel frame on a reaction slab. The columns were transported to the reaction steel frame using an overhead bridge crane. They were positioned on the reaction frame with the help of a $300 \mathrm{kN}$ hydraulic jack which was used to help position the setup's steel plates and lock the column into place with the assembly steel beams.

Vertical load application was done using a hydraulic jack with a $300 \mathrm{kN}$ capacity attached to a manual hydraulic pump. The hydraulic jack was placed under the column on the reaction slab. A $300 \mathrm{kN}$ capacity load cell was placed at the column's top. All strains and load cell readings are recorded digitally on a microcomputer. Some of the testing equipment was removed just prior to failure to avoid damage.

\section{Test results}

\subsection{Displacements}

Maximum displacements were measured by digital indicator R3 
Figure 5 - Connector positioning

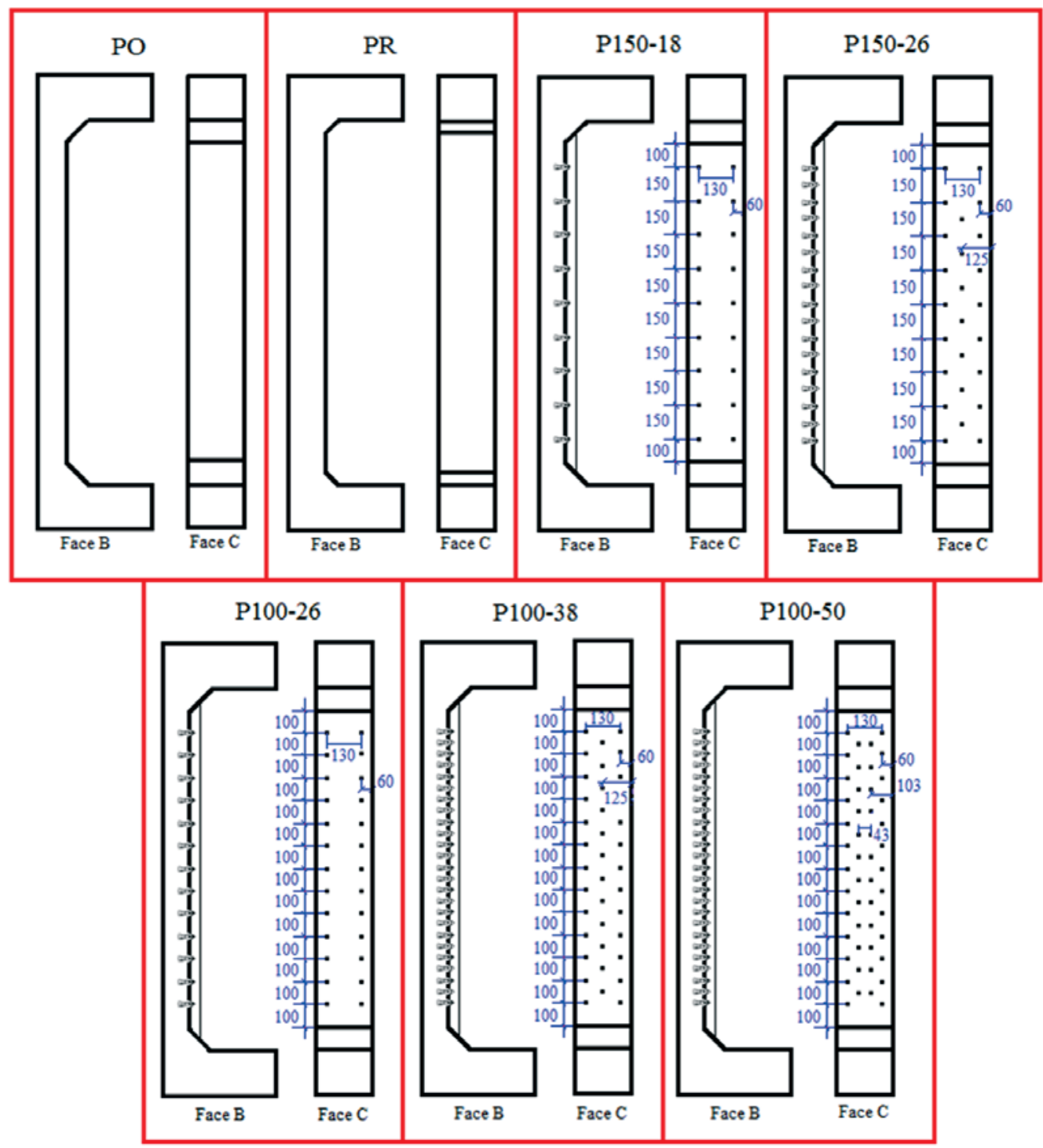

positioned at column mid-height and results are shown in Figure 9 for all columns. The dotted vertical line refers to Brazilian Concrete Code NBR 6118 [8] displacement limit of L/250 for bars in flexure at service limit state conditions, which was used in this study only as a comparison parameter.

The highest measured displacement occurred for the original column PO and measured $26 \mathrm{~mm}$, followed by displacements for reference column PR. Column P150-26 with 26 connectors showed highest displacements for the strengthened columns. All strengthened columns showed displacement curves with larger slopes than original column PO indicating the jacketing technique reduces column displacements since the size of the cross section increases. Column PR had the same dimensions as the strengthened columns and displacement curves had similar slopes.

Strengthened columns were more rigid as the number of connectors increased. The displacement curve for column P100-50 with the greatest number of connectors is closest to the displacement curve for reference column PR.

\subsection{Steel strains}

Figure 10 shows load vs strain curves for strain gauges placed on tension steel reinforcement at column mid-height along tensioned face T. All columns show that the longitudinal steel placed along in tension face were subjected to tension since 
Figure 6 - Strain gauge positioning on steel longitudinal reinforcement, on compressed concrete

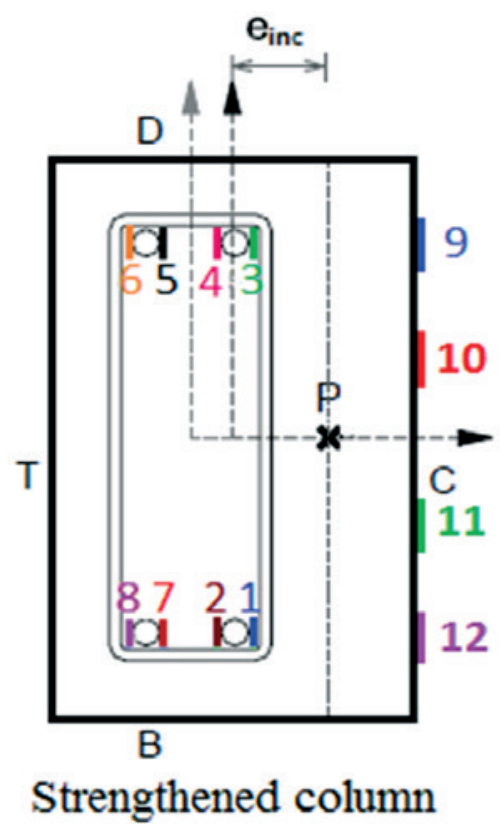

\section{Figure 7 - Displacement indicator positioning}

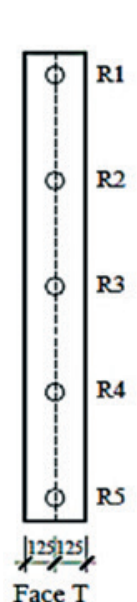

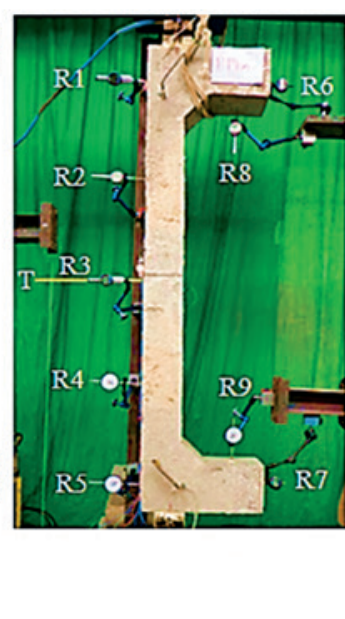

initial loading, except for column P150-18 which shows a small level of compression at initial loads. Only the steel in column PO showed strains above the yielding, indicate by the dotted vertical line. Since some of the recording equipment was removed before failure (at about $80 \%$ of ultimate load), it may be possible that longitudinal steel may have yielded in other columns as well, especially columns $\mathrm{P} 100-26$ and $\mathrm{P} 150-26$ which show flatter curves at

Figure 8 - Test setup

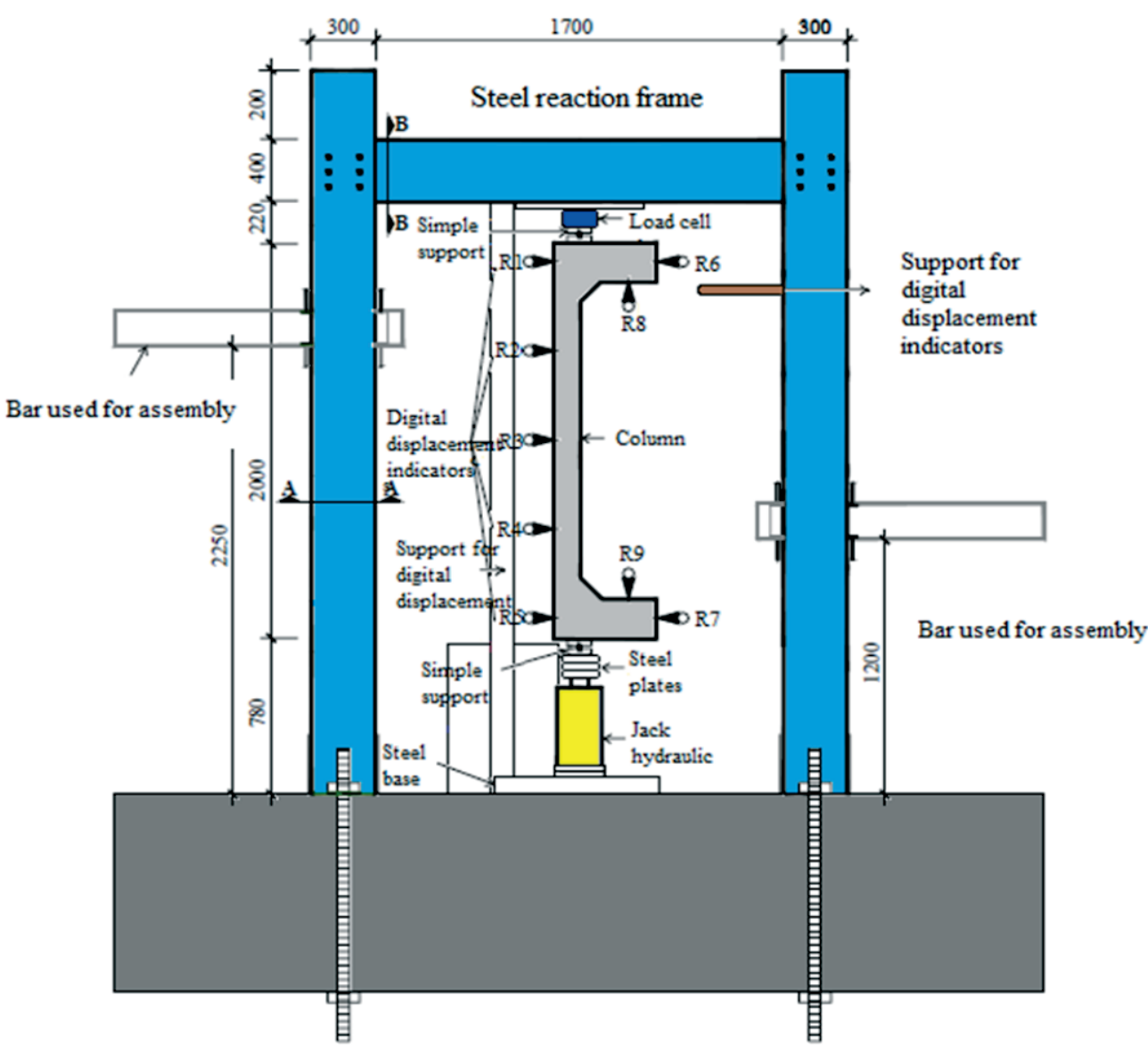




\section{Figure 9 - Displacements measured by indicator R3 for all columns}
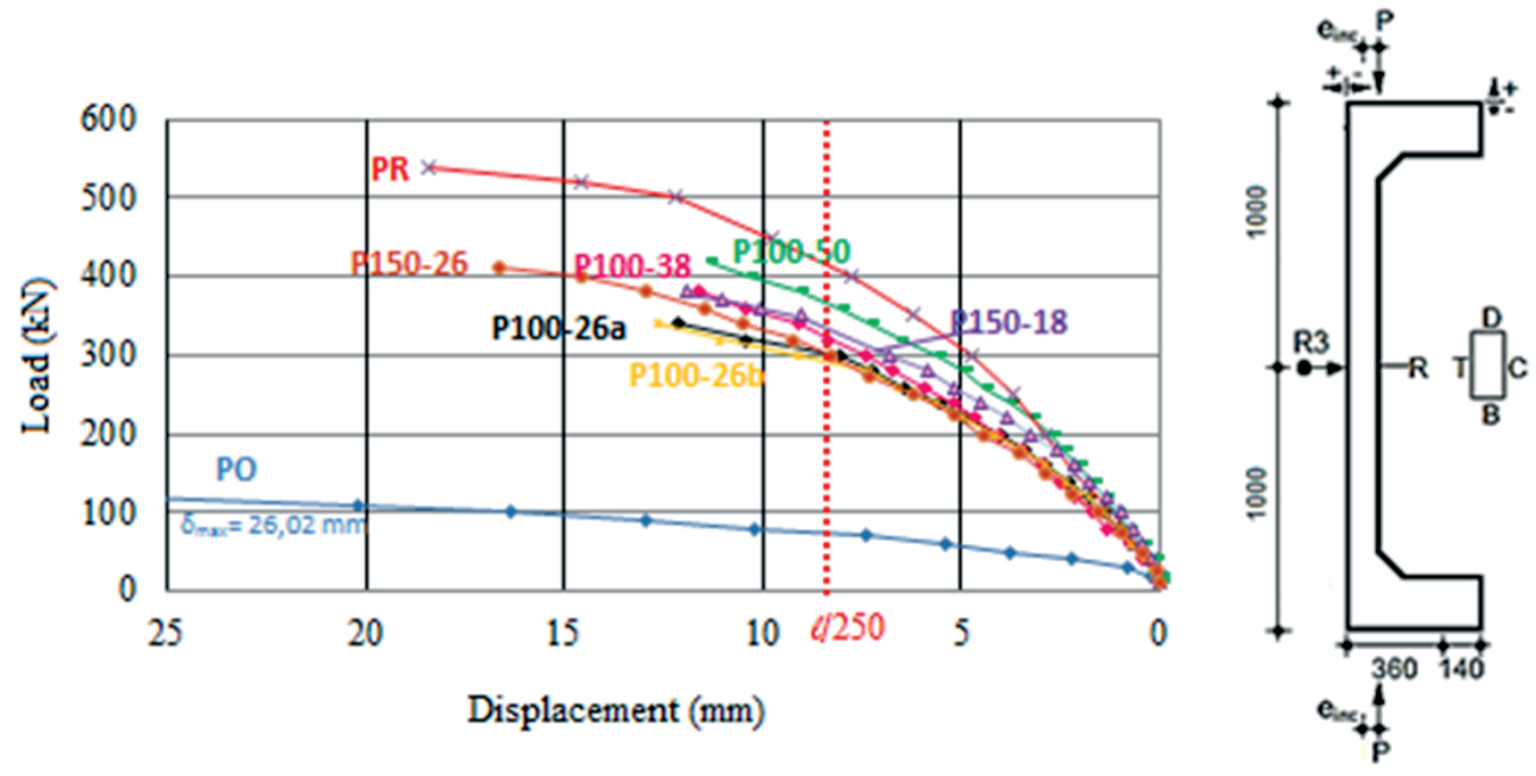

higher loads. Steel strains in strengthened columns were smaller than those strains in the original column $\mathrm{PO}$ and higher than reference column PR.

In general, strengthened column stiffnesses increased with an increase in the number of connectors. The strengthened columns, with the exception of column P150-18, had higher steel strains than those obtained in the reference column PR and smaller that those obtained in original column PO.

Figure 11 shows load vs strain curves for strain gauges placed on the compression steel reinforcement at column mid-height. Column PR showed greatest compressive strains. With the exception of column P100-26, all strengthened columns show a change in slope near the end of the test with a reduction in the compression strains indicating a sharp movement of the neutral axis of the cross section. However, this did not occur in columns PO and PR.

\subsection{Concrete strains}

For analysis of concrete strains, only the results from the strain gauges with the largest strains were considered. Figure 12 shows

\section{Figure 10 - Load vs tension steel strain curves}

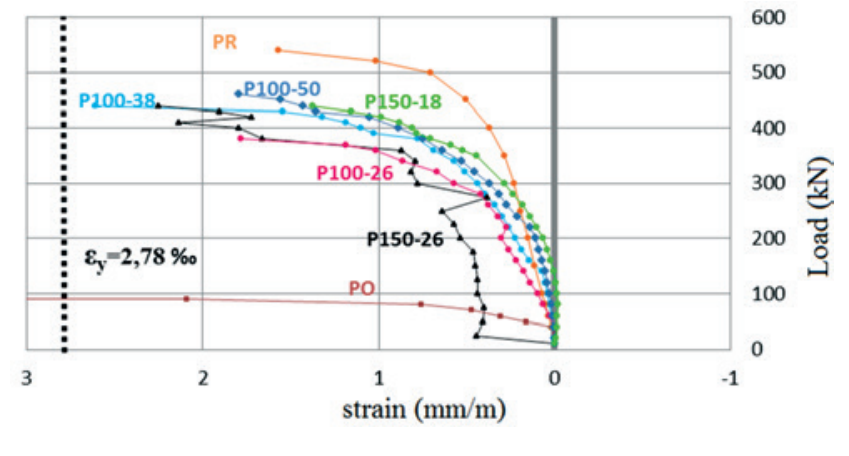

load vs concrete strains for all columns. The two vertical dotted lines in Figure 12 indicate the ultimate concrete strains specified in ACl Code 318 [9] and in Brazilian Code NBR 6118 [8] at $3.0 \mathrm{~mm} / \mathrm{m}$ and at $3.5 \mathrm{~mm} / \mathrm{m}$, respectively.

Concrete strains in strengthened columns, except for column P15018 , reached the $\mathrm{ACl}$ Code ultimate strain. Although monolithically cast columns PO and PR and strengthened column P150-18 did not reach the Code's ultimate strain, their behavior was similar to the other columns which is shown by almost flat, horizontal curves near ultimate loading. No column strains were above the ultimate concrete strain established by the Brazilian Code and strains in column P150-26 were closest to its ultimate concrete strain value. All columns showed compressive strains since the start of loading. Again, the slope of the curves is related to the number of connectors. An increase in the number of connectors indicates higher stiffness for the strengthened columns, except for column P15018 which behaved similar to column P100-50. Strains for column P100-26 are smaller than other columns, except the original column $\mathrm{PO}$, which can be explain by the fact that the test had to be interrupted and the column reloaded with some cracking already

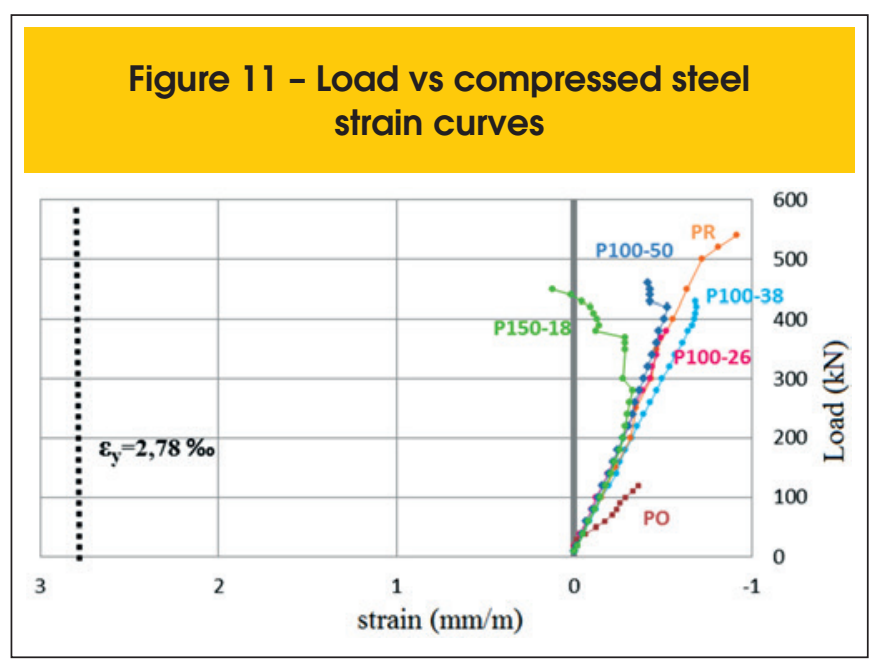




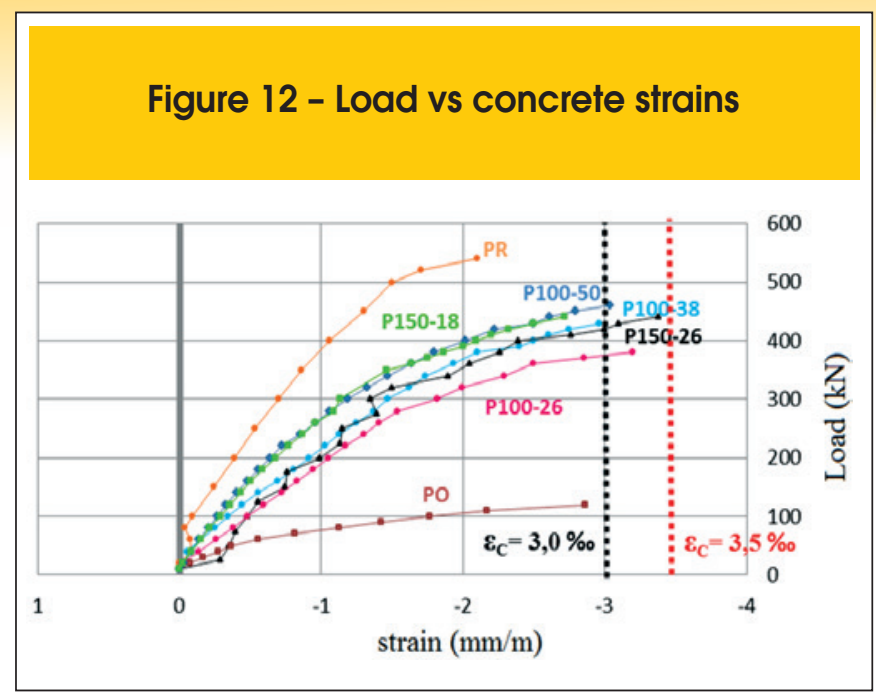

in place, reducing its stiffness. All strengthened columns showed stiffness higher than original column PO and smaller than reference column PR.

\subsection{Ultimate loads and modes of failure}

In this section, ultimate loads and connection ratio in monolithic columns PO and PR were taken as parameters for comparisons. The additional parameter is connector ratio $T_{c h}$ which is defined as the ratio between the total cross sectional area of all connectors in a column and the area of the new concrete/old concrete interface. Table 1 shows ultimate loads, modes of failures, material properties of the concrete substrate and the concrete used for jacketing, connector ratio $T_{c h}$, and ratios between ultimate loads. The table also presents data from previous studies done by Omar [5], Sahb [6] e Nascimento [7] which analyzed similar columns.

Rupture in all columns occurred at the column's mid-height region as shown in Figure 13. Only column P150-26 had concrete ruptured slightly above the column mid-height. Figure 14 shows

Figure 13 - Rupture surfaces

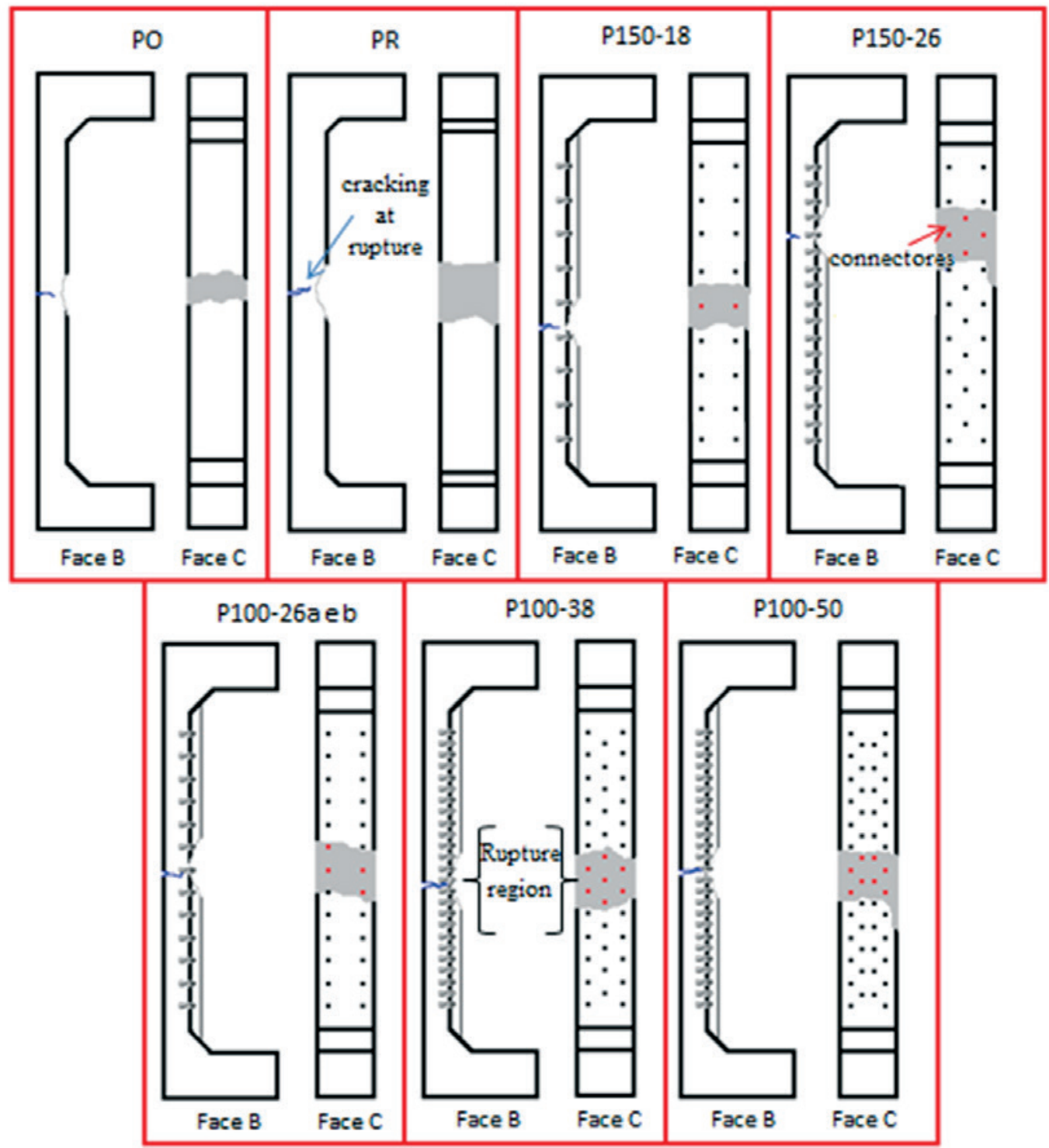


Table 1 - Ultimate loads, modes of failures, concrete compressive strengths, connector ratio $t_{c h}$, and ratios between ultimate loads

\begin{tabular}{|c|c|c|c|c|c|c|c|}
\hline Column & $\begin{array}{c}P_{u} \\
(\mathbf{k N})\end{array}$ & $\begin{array}{c}f_{c}^{\text {sub }} \\
(\mathrm{MPa})\end{array}$ & $\begin{array}{c}f_{c}^{\text {ref }} \\
(\mathrm{MPa})\end{array}$ & $\begin{array}{l}\mathrm{T}_{\mathrm{ch}} \\
(\%)\end{array}$ & $\begin{array}{l}\mathrm{P}_{\mathrm{u}} / \mathrm{P}_{\mathrm{u}} \\
(\mathrm{PO})\end{array}$ & $\begin{array}{c}P_{u} / P_{u} \\
(P R)\end{array}$ & $\begin{array}{l}\text { Mode } \\
\text { of failure }\end{array}$ \\
\hline PO & 126,7 & 41,9 & - & - & 1,00 & 0,23 & YS - CC \\
\hline PR & 542,2 & 41,30 & - & - & 1,28 & 1,00 & YS - CC \\
\hline P150-18 & 453,2 & 41,4 & 39,7 & 0,26 & 3,58 & 0,84 & DC \\
\hline P150-26 & 442,5 & 41,5 & 40,1 & 0,37 & 3,49 & 0,82 & DC \\
\hline P100-26 & 389,9 & 43,3 & 45,0 & 0,37 & 3,08 & 0,72 & DC \\
\hline P100-38 & 441,0 & 43,5 & 45,5 & 0,55 & 3,48 & 0,81 & DC \\
\hline P100-50 & 469,9 & 43,6 & 45,7 & 0,72 & 3,70 & 0,87 & DC \\
\hline PA-R9 ${ }_{s}$ & 553,4 & 39,9 & 52,0 & 0,25 & 4,36 & 1,02 & DC \\
\hline PB-R9-8 s & 626,3 & 41,2 & 52,5 & 0,37 & 4,94 & 1,16 & DC \\
\hline PC35。 & 380,0 & 25,1 & 46,2 & 0,24 & 3,00 & 0,70 & DC \\
\hline PC55。 & 506,0 & 21,5 & 46,8 & 0,24 & 3,99 & 0,93 & DC \\
\hline $\mathrm{P}_{\mathrm{N}}$ & 480,0 & 38,5 & 35,0 & 0,04 & 3,80 & 0,89 & DC \\
\hline$P 8_{N}$ & 520,0 & 38,2 & 34,5 & 0,07 & 4,10 & 0,96 & $\mathrm{CC}$ \\
\hline \multicolumn{8}{|c|}{ 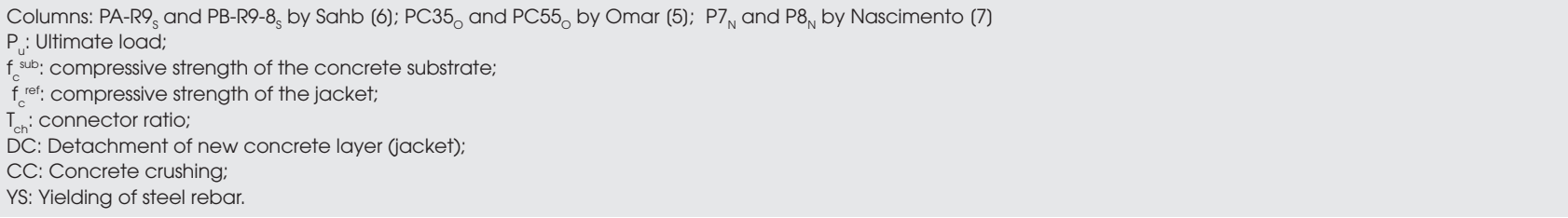 } \\
\hline
\end{tabular}

photographs of these ruptures for several columns. None of the connectors failed.

Ultimate load capacity increased of strengthened columns and ultimate loads ranged from 3.1 to 3.7 times the ultimate load capacity for original column PO. This strength gain was in direct proportion to the number of connectors for each column, with the exception of column P150-18. Column P150-18 has a low connector ratio of $0.25 \%$ but its ultimate load capacity was smaller than only two columns: P100-50 and PR.

Columns P150-18 and P150-26 had smaller ultimate loads than columns PA-R9S e PB-R9-8S tested by Sahb [6] which had the same number of connectors and distribution scheme. This difference can be attributed to different concrete compressive strengths of jacket as shown in the third column of Table 1.

Omar's [5] column PC35 had an ultimate load close to strengthened column P100-26 with a higher connector ratio. Columns tested by Nascimento [7], with smaller reinforcing ratios and lower concrete strengths, had ultimate loads four times higher than original column PO. This can be explained by use of different wedge bolt installation techniques, not to mention that Nascimento's column $P 8_{N}$ was the only one in these studies that did not have the concrete jacket detached but showed concrete crushing.

Table 2 shows results obtain from researchers mentioned above such as column eccentricity, thickness of the strengthening layer, maximum strains and steel yield strains.

\section{Conclusions}

Five reinforced concrete columns strengthened using a partial jacket consisting of a $35 \mathrm{~mm}$ self-compacting concrete layer added to its most compressed face were tested in combined compression and uniaxial bending until rupture. Wedge bolt connectors were used to increase bond at the interface between the two concrete

\section{Figure 14 - Photos of concrete crushing at column mid-height}

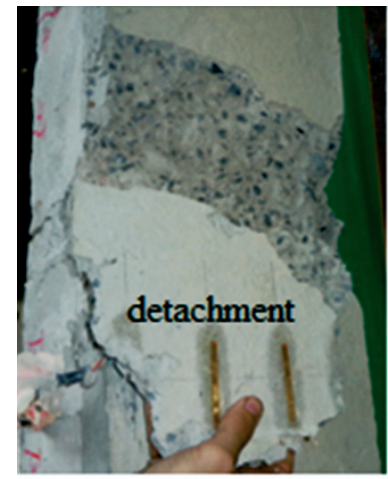

P100-26

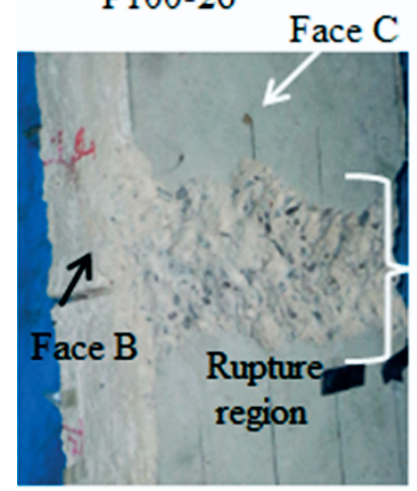

PO

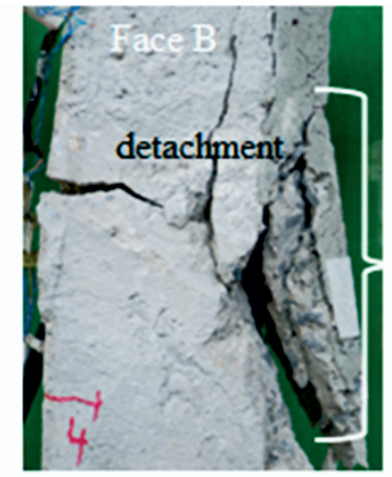

P100-38

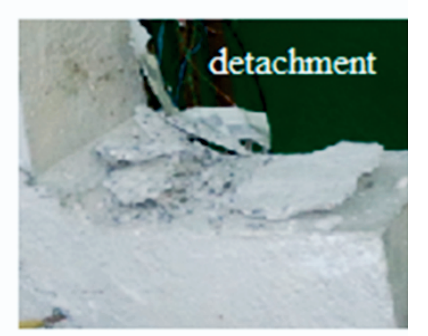

P100-50

P100-50 


\section{Table 2 - Maximum strains}

\begin{tabular}{|c|c|c|c|c|c|c|}
\hline Column & $\underset{(k N)}{P_{u}}$ & $\stackrel{e}{e}$ & $\begin{array}{l}\text { Erc } \\
(\mathrm{mm})\end{array}$ & $\begin{array}{c}\varepsilon_{\mathrm{s}} \max \\
(\mathrm{mm} / \mathrm{m})\end{array}$ & $\begin{array}{c}\varepsilon_{\mathrm{c}} \max \\
(\mathrm{mm} / \mathrm{m})\end{array}$ & $\begin{array}{c}\varepsilon_{\mathrm{y}} \\
(\mathrm{mm} / \mathrm{m})\end{array}$ \\
\hline $\mathrm{PO}$ & 126,7 & 60,0 & - & $>2,78$ & 2,86 & 2,78 \\
\hline PR & 542,2 & 42,5 & - & 1,79 & 2,10 & 2,78 \\
\hline P150-18 & 453,2 & 42,5 & 35 & 1,50 & 2,71 & 2,78 \\
\hline P150-26 & 442,5 & 42,5 & 35 & 2,27 & 3,38 & 2,78 \\
\hline P100-26 & 389,9 & 42,5 & 35 & 1,78 & 3,20 & 2,78 \\
\hline P100-38 & 441,0 & 42,5 & 35 & 2,61 & 2,96 & 2,78 \\
\hline P100-50 & 469,9 & 42,5 & 35 & 1,79 & 3,03 & 2,78 \\
\hline PA-R9s & 553,4 & 42,5 & 35 & 1,00 & 1,37 & 2,95 \\
\hline PB-R9-8 & 626,3 & 42,5 & 35 & 1,87 & 2,68 & 2,95 \\
\hline PC35。 & 380,0 & 42,5 & 35 & 1,47 & 2,43 & 2,87 \\
\hline PC55。 & 506,0 & 32,5 & 55 & 1,43 & 2,49 & 2,87 \\
\hline$P 7_{N}$ & 480,0 & 42,5 & 35 & 4,30 & - & 2,42 \\
\hline $\mathrm{P} 8_{\mathrm{N}}$ & 520,0 & 42,5 & 35 & 2,30 & 3,80 & 2,42 \\
\hline \multicolumn{7}{|c|}{$\begin{array}{l}\text { Columns: PS - Sahb (6), PO - Omar (5), PN - Nascimento (7) } \\
\text { e - initial eccentricity; } \\
\text { Erc - thickness of the strengthening layer at the most compressed face; } \\
\varepsilon_{\mathrm{s}} \text { max -maximum steel strain; } \\
\varepsilon_{\mathrm{c}} \text { max - maximum concrete strain; } \\
\varepsilon_{\mathrm{y}} \text {-steel yield strain, obtained by rebar specimen testing. }\end{array}$} \\
\hline
\end{tabular}

layers of different ages. Two columns were cast monolithically, named PO (original column) e PR (reference column).

Ultimate load capacity of all strengthened columns was 3.1 to 3.7 times the ultimate load capacity for original column PO but always smaller than the ultimate capacity of reference column PR. Column P100-50 had the highest ultimate load with the greatest number of connectors and, in general, the increase in ultimate load was in direct proportion to the number of connectors, with the exception of column P150-18.

All strengthened columns had smaller horizontal displacements than the original column PO which had a smaller cross section. Stiffness increased with an increase in connector ratio. All columns had smaller stiffnesses than the reference column PR.

Only the longitudinal steel in column PO yielded, but longitudinal steel strain in the other columns were close to yielding strain as their load-strain curves became very flat at about $80 \%$ of ultimate load.

Rupture in all columns occurred after detachment of the concrete jacket at column mid-height. Stiffness of the strengthened columns was in direct proportion to the number of connectors. No connector failed in shear. More research is needed with respect to bond of concrete at different ages since concrete detachment occurred just prior to rupture indicating that perfect ductility was not obtained although a large increase in ultimate load occurred.

\section{Acknowledgments}

The authors wish to thank to financial contributions of the Brazilian government through its research agencies CAPES and CNPq and the contribution of private companies such as Realmix, Carlos Campos Consultoria Ltda. and Impercia.

\section{References}

[1] GOMES, A \& APPLETON, J. Strengthening of reinforced concrete structures by use of jacketing. RPEE, Lisboa, 1998.

[2] IBRAHIM, H. H. H.; MACGREGOR, J. G. Tests of eccentrically loaded high-strength concrete columns. ACI Structural Journal, v. 93, n. 5, p. 585-594, September-October 1996.

[3] ARAÚJO, L. M. B. Análise Teórica e Experimental de Pilares de Concreto Submetidos à Flexão Normal Composta. Master's Dissertation. Federal University of Goias, Goiânia, GO, 196p, 2004.

[4] ADORNO, A. L. C. Análise Teórica e Experimental de Pilares em Concreto Simples e Armado sob Flexo-Compressão Reta. 2004. 399p. Thesis (D.Sc.) - Civil and Enviornmental Engineering Department/UnB, Brasília, DF, 2004.

[5] OMAR, M. Y. M. Experimental analysis of reinforced concrete columns strengthened with self-compacting concrete. IBRACON Structures and Materials Journal, 2010.

[6] SAHB, K. F. P. Análise Experimental de Pilares de Concreto Armado Submetidos à Flexo-Compressão, Reforçados com Concreto Auto Adensável e Chumbadores. 224f. Master's Dissertation. Federal University of Goias, Goiânia, Goiás, 2008.

[7] NASCIMENTO, P. P. Análise Experimental de Pilares de Concreto Armado Submetidos à Flexo-Compressão, Reforçados com Concreto Auto Adensável e Conectores. Master's Dissertation , Federal University of Goias, Goiânia, Goiás, 2009.

[8] ABNT: Associação Brasileira de Normas Técnicas. NBR 6118:2007 - Design of Structures in Concrete - Procedures. Rio de Janeiro, 2007.

[9] $\mathrm{ACl}$ COMMITTEE 318. Building Code Requirements for Reinforced Concrete and Commentary - ACl 318M/02. Detroit, American Concrete Institute, 2011. 